\title{
Heart Failure Etiology in Patients Undergoing Cardiac Resynchronization Therapy. Is It Relevant?
}

Silvia DEACONU1,2, Alexandru DEACONU1,2, Alina SCARLATESCU1,2, loana PETRE1,2, Sebastian ONCIUL1,2, Aura VIJIAC ${ }^{1,2}$, Amalia PETRE², Gabriela MARASCU', Corneliu IORGULESCU², Andrei Dan RADU1,2, Stefan BOGDAN ${ }^{1,2}$, Radu VATASESCU1,2, Maria DOROBANTU1,2

\begin{abstract}
Background: Cardiac resynchronization therapy (CRT) is an established treatment for heart failure with reduced ejection fraction (HfrEF). Etiology may influence the outcome of patients undergoing CRT. Objective: to evaluate whether etiology (ischemic vs non-ischemic) influences the response to CRT and overall outcome. Methods: Our study included HFrEF patients undergoing CRT between January 2017-November 2019. We assessed right ventricle (RV) and left ventricle (LV) function using transthoracic echocardiography at baseline and one year after CRT. The response to CRT was defined by a decrease of more than 15\% of left ventricle systolic volume. Patients were divided in two groups: ischemic and non-ischemic based on personal history. Adverse events (HF related hospitalizations and deaths) were tracked for $33 \pm 12.8$ months. Results: 52 patients undergoing CRT were included (64 \pm 13.5 years, $55.7 \%$ male, $70 \%$ non-ischemic etiology) The two groups were similar considering LV systolic baseline parameters and volumes. Ischemic etiology was associated with non-LBBB morphology on ECG $(p=0.03)$, a more severe LV diastolic dysfunction using E/e ratio $(p<0.05)$, and a more severe RV dysfunction using TAPSE $(p=0.008)$ and $R V$ fractional area change $(F A C)(p<0.05)$. There was no significant difference in CRT response between ischemic and non-ischemic etiology. 14 (26.9\%) patients had events (10 hospitalizations and 4 deaths) with a higher prevalence in the ischemic group (58.33\% vs $25 \%, p=0.01)$. Univariate Cox regression analysis reported a higher risk of cardiovascular events for ischemic etiology (HR 2.4, 95\% $\mathrm{Cl}$ [0.8-8.1], p <0.05). In our cohort there was no significant difference in use of an implantable cardioverter-defibrillator in addition to CRT between ischemic and non-ischemic group (64.2\% respectively $63.3 \%, p=0.3)$. Conclusion: Our study shows that ischemic and nonischemic HF patients had similar response to CRT. However, ischemic etiology was associated with a higher risk of adverse cardiovascular events and a worse RV systolic dysfunction at baseline.
\end{abstract}

Keywords: cardiac resynchronization therapy, heart failure etiology, right ventricle dysfunction, TAPSE, heart failure with reduced ejection fraction.

\section{Rezumat}

Context: Terapia de resincronizare cardiacă (CRT) este un tratament eficient în insuficiența cardiacă (IC) cu fracție de ejecție redusă. Etiologia poate influența prognosticul pacienților tratați prin CRT. Obiectiv: stabilirea influenței etiologiei (ischemică versus non-ischemică) asupra răspunsului la CRT și în prognosticul pacienților tratați prin CRT. Metode: Studiul a inclus pacienți cu IC cu fracție de ejecție redusă tratați prin CRT între ianuarie 2017-noiembrie 2019. Am evaluat funcția ventriculului stâng (VS) și drept (VD) înainte de CRT și după 1 an. Răspunsul la CRT a fost

"Carol Davila" University of Medicine and Pharmacy, Bucharest, Romania

${ }^{2}$ Department of Cardiology, Emergency Clinical Hospital, Bucharest, Romania

\section{Corresponding author.}

Alexandru DEACONU, Department of Cardiology, Clinical

Emergency Hospital, "Carol Davila” University of Medicine and

Pharmacy, Bucharest, Romania.

E-mail: alexandru_deaconu@yahoo.com 
definit de scăderea cu peste 15\% a volumului telesistolic al VS la 1 an post CRT. Pacienții au fost împărțiți în două grupuri în funcție de istoric: ischemici și non-ischemici. Monitorizarea pentru evenimente cardiovasculare adverse

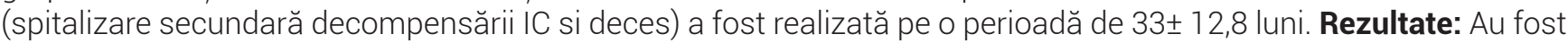
incluși 52 pacienți ( $64 \pm 13,5$ ani , 55,7\% sex masculin , 70\% non-ischemici). Cele două grupuri au fost similare în ceea ce privește fracția de ejecție VS și volumele VS bazale. Etiologia ischemică a fost asociată cu morfologie non-BRS pe ECG ( $p=0,03)$, cu disfuncție diastolică VS mai severă, evaluată prin raportul E/e $(p<0,05)$, și o disfuncție sistolică mai severă a VD evaluată prin TAPSE $(p=0,008)$ și fracția de schimbare a ariei VD $(p<0,05)$. Nu au existat diferențe semnificative în ceea de privește răspunsul la CRT în cele două grupuri. 14 (26,9\%) pacienți au avut evenimente (10 spitalizări și 4 decese), predominant pacienții ischemici (58.33\% vs 25\%, p=0,01). Analiza de regresie CoX univariată a raportat un risc crescut de evenimente pentru etiologia ischemică (HR 2.4, 95\% Cl [0,8-8,1], p <0,05). În lotul studiat nu există o diferență semnificativă în utilizarea defibrilatorului automat asociat CRT, între pacienții ischemici și non ischemici $(64,2 \%$ respectiv $63,3 \%, p=0,3)$. Concluzie: În lotul studiat răspunsul la CRT a fost similar între pacienții ischemici și non-ischemici. Etiologia ischemică, însă, este asociată cu un risc mai mare de evenimente cardiovasculare și cu o disfuncție sistolică mai severă a VD anterior CRT.

Cuvinte cheie: terapia de resincronizare cardiacă, etiologia insuficienței cardiace, disfuncția de ventricul drept, TAPSE, insuficiența cardiacă cu fracție de ejecție redusă.

\section{INTRODUCTION}

Cardiac resynchronization therapy (CRT) is an efficient therapeutic approach for the management of patients with symptomatic heart failure (HF) with reduced left ventricular ejection fraction (LVEF) $\leq$ $35 \%$ and a QRS duration of $\geq 130$ ms with left bundle branch block (LBBB)/non-LBBB morphology ${ }^{1,2}$. CRT improves LV function by alleviating AV, interand intra-ventricular synchrony, also reducing functional mitral regurgitation (MR) and inducing LV reverse remodelling ${ }^{3}$.

Multiple studies discuss the importance of etiology in assessing long-term outcome of patients undergoing CRT. Differences in survival rates and improvement of LV parameters have been described in ischemic compared to non-ischemic patients ${ }^{4}$.

\section{MATERIAL AND METHODS}

\subsection{Study patients}

We conducted a prospective, single-center study that involved 52 patients with HfrEF treated with CRT in the Cardiology Department of Bucharest Clinical Emergency Hospital, Romania, during January 2017November 2019. The study was approved by the Ethics Committee of the Clinical Emergency Hospital Bucharest.

We enrolled patients with HfrEF with CRT indication, corresponding to current ESC Guidelines ${ }^{1}$.
The study population was analyzed for age, sex, HF etiology: ischemic versus non-ischemic (according to coronary angiography), comorbidities, QRS duration and morphology. Patients were divided in two groups ischemic and non-ischemic according to history and coronary angiography. The presence of coronary stenosis, previous angioplasty, myocardial infarction placed the patient in the ischemic group.

Standard echocardiography was performed by certified sonographers (Vivid E9, GE Vingmed Ultrasound AS, Horten, Norway).

Left ventricle echocardiographic assessment. Ejection fraction and LV volumes (end-systolic and end-diastolic) were assessed using the apical 4-chamber view, by Simpson's biplan equation. E/e was calculated as a ratio between pulsed wave early ventricular wave filing (E) and early myocardial velocity (e) measured by tissue doppler imaging. Patients were classified as responders by a $\geq 15 \%$ reduction of $\mathrm{LV}$ end systolic volume by echocardiographic assessement after 1-year.

Right ventricle echocardiographic evaluation. The RV and pulmonary circulation function were assessed by measuring TAPSE and PASP.

- TAPSE was measured using the apical four-chamber view with M-mode cursor placed through the lateral tricuspid annulus TAPSE was calculated as the peak excursion of the tricuspid annulus from the end of diastole to end systole $(\mathrm{mm})^{5}$. PASP was estimated using tricuspid regurgitant velocity (TRV) and right atrial pressure (RAP) and as 
follows: 4(TRV $\left.{ }^{2}\right)+$ RAP. RAP was assumed based on inferior vena cava (IVC) measurements, according to guidelines 5 .

- $\quad$ RV Global longitudinal strain (RVGLS) was measured using two-dimensional images acquired from the four-chamber view. The offline analysis was performed using the strain software (EchoPAC, General Electric Vingmed Ultrasound). The endocardial border of the right ventricle was traced manually and tracked by the software.

- RV fractional area change (RVFAC) was obtained by tracing the RV end-diastolic area and end-systolic area in the apical 4-chamber view. The formula for RVFAC is: (RV end diastolic area $-\mathrm{RV}$ end systolic area $) / \mathrm{RV}$ end diastolic area $\times 100$.

\subsection{Follow-up period}

The total follow-up period was $33 \pm 12.8$ months after CRT. The patients were monitored for evolution of NYHA class and clinical events: HF-related hospitalizations and cardiovascular death. Echocardiography was performed at baseline and one year after CRT.

\subsection{Statistical analysis}

Results were expressed as mean \pm standard deviation for continuous variables and percentage for categorical variables. Differences between continous variables were analyzed with the paired sample t-test (from baseline to one year) and independent $t$ test. Differences between categorical variables were assessed with chisquare test. A test was considered significant if $p$ value $<0.05$. Kaplan-Meier analysis was used to assess the differences in survival among subjects according to etiology of heart failure, ischemic vs non ischemic. Univariate Cox regression analysis was used to assess risk of cardiovascular events associated with ischemic etiology. All analyses and graphs were performed using STATA Statistical Software (StataCorp, College Station, TX, USA; version 16 for macOS).

\section{RESULTS}

\subsection{Baseline characteristics}

A total of 52 were included in our study between January 2017 - November 2019.

The baseline characteristics of the study population are listed in Table 1.

Table 1. Baseline characteristics of the study population and according to etiology

\begin{tabular}{|c|c|c|c|c|}
\hline Parameters & $\begin{array}{c}\text { Overall } \\
n=52\end{array}$ & $\begin{array}{c}\text { Ischemic } \\
\mathrm{n}=15\end{array}$ & $\begin{array}{c}\text { Non-ischemic } \\
\quad \mathbf{n}=37\end{array}$ & $p$ value \\
\hline Age (yrs) & $64 \pm 13.5$ & $69.60 \pm 20.75$ & $63.29 \pm 14.22$ & 0.12 \\
\hline $\operatorname{Men}(\%)$ & 55.77 & 80 & 46 & 0.02 \\
\hline$B M I(\mathrm{~kg} / \mathrm{m} 2)$ & $28 \pm 5.32$ & $27.99 \pm 4.89$ & $27.7 \pm 5.35$ & 0.88 \\
\hline$H T N(\%)$ & 71.43 & 85.71 & 64.71 & 0.1 \\
\hline \multicolumn{5}{|l|}{ NYHA Class (\%) } \\
\hline$I I$ & 27.50 & 9.09 & 34.48 & 0.2 \\
\hline$I I I$ & 37.50 & 54.55 & 31.03 & \\
\hline$I V$ & 35.00 & 36.36 & 34.48 & \\
\hline Dyslipidemia (\%) & 63.83 & 64.2 & 63.6 & 0.9 \\
\hline Diabetes (\%) & 40.82 & 57.14 & 34.29 & 0.1 \\
\hline Smoking (\%) & 38.3 & 35.7 & 40.6 & 0.8 \\
\hline$\angle B B B(\%)$ & 70.7 & 50 & 81.48 & 0.03 \\
\hline$I C D(\%)$ & $63.6 \%$ & $64.2 \%$ & $63.3 \%$ & 0.3 \\
\hline
\end{tabular}

BMI - Body mass index; HTN - arterial hypertension; DM - diabetes mellitus; NYHA - New York Heart Academy. ICD -implantable cardioverter- defibrillator 
The patients ischemic etiology of HFrEF were more likely to be males and with non-LBBB morphology of the QRS on ECG. In our cohort there was no significant difference in use of an implantable cardioverter-defibrillator in addition to CRT between ischemic and non-ischemic group ( $\mathrm{p}=0.3)$

Table 2. Baseline electrocardiographic and echocardiographic characteristics

\begin{tabular}{|l|l|l|l|l|}
\hline \multicolumn{1}{|c|}{ Parameters } & \multicolumn{1}{c|}{ Overall } & \multicolumn{1}{c|}{ Ischemic } & \multicolumn{1}{c|}{ Non-ischemic } & \multicolumn{1}{c|}{$\boldsymbol{p}$-value } \\
\hline ORS $(\mathrm{ms})$ & $170.27 \pm 3.51$ & $170 \pm 30$ & $170.38 \pm 17.31$ & 0.961 \\
\hline LVEF $(\%)$ & $28.94 \pm 1.32$ & $28 \pm 7.52$ & $29.34 \pm 8.38$ & 0.648 \\
\hline LAESV $(\mathrm{ml})$ & $84.35 \pm 7.99$ & $104.33 \pm 47.45$ & $79.31 \pm 38.38$ & 0.147 \\
\hline RAESV $(\mathrm{ml})$ & $49.66 \pm 5.33$ & $60.77 \pm 30.89$ & $44.11 \pm 25.06$ & 0.144 \\
\hline$L V E S V(\mathrm{ml})$ & $151.89 \pm 15.09$ & $154.81 \pm 93.68$ & $150.75 \pm 96.14$ & 0.905 \\
\hline LVEDV $(\mathrm{ml})$ & $205.35 \pm 16.72$ & $208.36 \pm 100.38$ & $204.17 \pm 107.77$ & 0.915 \\
\hline FAC $(\%)$ & $41.82 \pm 3.45$ & $32.16 \pm 17.63$ & $46.174 \pm 17.75$ & 0.029 \\
\hline TAPSE $(\mathrm{mm})$ & $21.38 \pm .52$ & $19.26 \pm 3.99$ & $22.24 \pm 3.39$ & 0.008 \\
\hline$R V G L S(\%)$ & $-12.65 \pm .90$ & $-10.7 \pm-5.16$ & $-13.61 \pm-5.18$ & 0.144 \\
\hline$s P A P(\mathrm{mmHg})$ & $34.82 \pm 1.89$ & $37.93 \pm 16.28$ & $33.56 \pm 12.53$ & 0.302 \\
\hline$E / e$ & $14 \pm 11.4$ & $18.4 \pm 19.04$ & $11.9 \pm 5.12$ & 0.03 \\
\hline
\end{tabular}

$L V E F$ - left ventricular ejection fraction; LAESV - left atrial end-systolic volume; RAESV - right atrial end-systolic volume; LVESV - left ventricular end-systolic volume; LVEDV - left ventricular end-diastolic volume; volume; FAC-Fractional area change; TAPSE - Tricuspid annular plane systolic excursion; $R V$ - Right ventricle; sPAP - Systolic pulmonary artery pressure. E/e - ratio between mitral pulsed wave $E$ and the average between septal and lateral TDI e wave

\subsection{LV parameters at baseline}

Patients with ischemic versus non-ischemic cardiomyopathy exhibited no significant differences regarding LV systolic function parameters, left atrial and ventricular volumes (Table 2). However, E/e ratio, diastolic dysfunction parameter, was higher is the ischemic group $(\mathrm{p}<0.05$, table 2$)$.

\subsection{RV systolic function at baseline}

The ischemic group presented, at baseline, a more severe $\mathrm{RV}$ dysfunction compared to the non-ischemic group. Before the procedure, the ischemic group showed a significantly decreased median TAPSE $(\mathrm{p}=0.008), \mathrm{RV}$ FAC $(\mathrm{p}<0.05$, Table 2$)$. 
Table 3. Evolution of electrocardiographic and echocardiographic parameters 1 year after CRT compared to baseline values ( $p$ value)

\begin{tabular}{|l|l|l|l|l|}
\hline \multicolumn{1}{|c|}{ Parameters } & \multicolumn{1}{c|}{ Ischemic } & \multicolumn{1}{c|}{ p value } & \multicolumn{1}{c|}{ Non-ischemic } & \multicolumn{1}{c|}{$\boldsymbol{p}_{\text {-value }}$} \\
\hline QRS $(\mathrm{ms})$ & $137.27 \pm 13.48$ & 0.002 & $138 \pm 15.45$ & $<0.001$ \\
\hline LVd $(\mathrm{mm})$ & $64.8 \pm 12.5$ & 0.17 & $61.13 \pm 10.7$ & 0.02 \\
\hline LVEF $(\%)$ & $37.2 \pm 15.2$ & 0.01 & $37.43 \pm 2.44$ & $<0.001$ \\
\hline LVESV $(\mathrm{ml})$ & $111.90 \pm 104.66$ & 0.01 & $111.36 \pm 88.01$ & $<0.001$ \\
\hline LVEDV $(\mathrm{ml})$ & $159.72 \pm 102.08$ & 0.009 & $171.22 \pm 103.48$ & 0.002 \\
\hline TAPSE $(\mathrm{mm})$ & $22.4 \pm 4.9$ & 0.009 & $22.8 \pm 2.8$ & 0.2 \\
\hline FAC $(\%)$ & $45.12 \pm 21.52$ & 0.6 & $45.68 \pm 15.55$ & 0.1 \\
\hline RV strain $(\%)$ & $-13.77 \pm-5.67$ & 0.09 & $-14.37 \pm-5.09$ & 0.07 \\
\hline sPAP $(\mathrm{mmHg})$ & $35.0 \pm 13.15$ & 0.5 & $32.72 \pm 8.89$ & 0.5 \\
\hline
\end{tabular}

$L V E F$ - left ventricular ejection fraction; $L V d$ - Left ventricle diameter, LVESV - Left ventricular end-systolic volume; LVEDVLeft ventricular end-diastolic volume; FAC-Fractional area change; TAPSE - Tricuspid annular plane systolic excursion

When we analysed the evolution after one year, in both groups there was significant revers remodelling of LV with increase in LVEF, however from the RV parameters only TAPSE improved at one year in the ischemic group (from $21.38 \pm .52 \mathrm{~mm}$ at baseline to $22.4 \pm 4.9$ at one year p 0.009).

The number of CRT volumetric responders was similar between the ischemic vs non ischemic $(70 \%$ respectively $76 \%, \mathrm{p}=0.81$ ).

\subsection{Survival analysis}

From a total of 52 patients, 14 had events (10 hospitalizations and 4 deaths). In the ischemic group 58.33\% of patients had events compared to $25 \%$ in the non -ischemic patients $(\mathrm{p}=0.01)$.

We performed survival analysis during the follow-up period ( $33 \pm 12.8$ months), which reports significant differences in total events between the ischemic and non-ischemic groups. Ischemic patients exhibited lower survival rates compared to the non-ischemic group (log rank test $\mathrm{p}<0.05$ ), as seen in Figure 1. Using Cox regression analysis ischemic etiology reports a higher risk of cardiovascular hospitalizations and death (HR 2.4, 95\% CI [0.8-8.1], p <0.05).

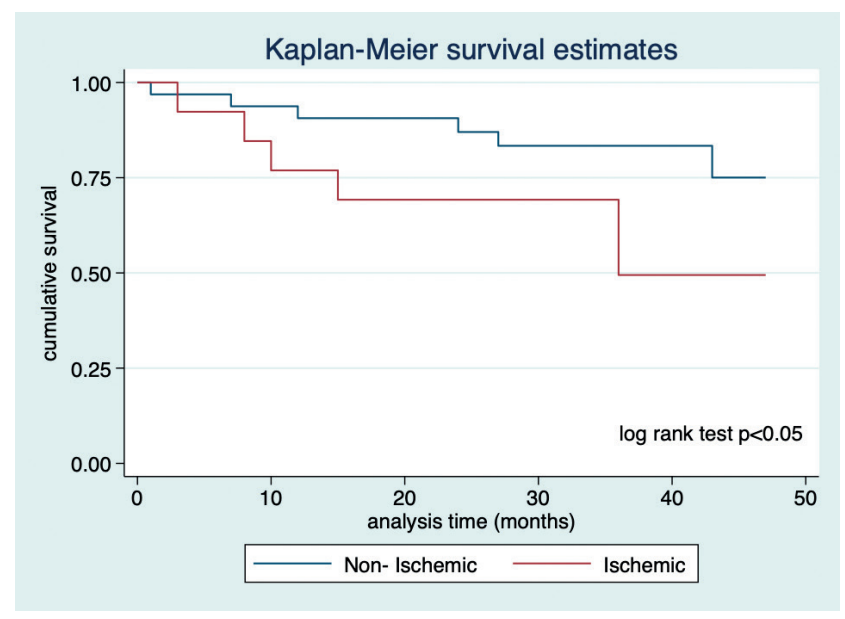

Figure 1. Kaplan Meier survival analysis according to etiology of left ventricular systolic dysfunction 


\section{DISCUSSION}

Our study provides valuable information about the influence of HfrEF etiology (ischemic vs non-ischemic) on CRT patients outcome. The main findings were:

- Ischemic etiology is associated with nonLBBB morphology on ECG, more severe LV diastolic dysfunction at baseline.

- Ischemic etiology was associated with a higher risk of adverse cardiovascular events at follow up.

- In our cohort ischemic patients had a more dysfunctional RV at baseline.

- One year after CRT, QRS decrease, LV reverse remodelling were similar between the two groups.

\subsection{Importance of etiology in HF patients undergoing CRT}

Our data showed a predominance of men in the ischemic group, with no statistically significant differences between ischemic and non-ischemic patients regarding mean age, NYHA class presentation and comorbidities. Patients with ischemic cardiomyopathy present more frequently with a non-LBBB pattern on ECG. A study by Martens et al suggests that non-LBBB configuration on ECG may be one of the reasons for the inferior results after CRT in ischemic patients ${ }^{4}$. Moreover, a meta-analysis of the main CRT trials suggested that patients with LBBB morphology exhibited a greater benefit on the composite endpoint of morbidity and mortality after CRT, compared with patients with non-LBBB morphology on $\mathrm{ECG}^{6}$.

In our study, at baseline, both groups ischemic and non-ischemic patients have similar LV systolic dysfunction at baseline. However, ischemic patients have a more severe $L V$ diastolic dysfunction. A study by Wang et al. also report that patients with ischemic etiology of $\mathrm{HF}$ had more restrictive filling patterns than the non-ischemic cardiomyopathy group ${ }^{7}$.

Many trials report that patients with ischemic cardiomyopathy experienced less LV remodelling after $\mathrm{CRT}^{8}$. Concerning survival rates, there are different results in literature, some trials report similar survival for ischemic and non-ischemic patients [2], and others found lower survival rates in case of ischemic etiology 8,4,9. McLeod et al reported a better response after CRT for non-ischemic patients compared with ischemic etiology and higher survival rates ${ }^{8}$. Martens et al found that ischemic etiology is associated with higher rate of mortality or $\mathrm{HF}$ readmission (hazard ratio $1.63 ; 95 \%$ [CI] 1.12-2.73; $\mathrm{p}=.011)^{4}$.

In our cohort, at 1 year follow-up, both ischemic and non-ischemic patients exhibit similar LV reverse remodelling. However, the ischemic etiology was associated with a higher risk of adverse cardiovascular events and death. Martens et al who obtained similar results consider that patients with an ischemic etiology have an intrinsically higher risk of mortality and HF hospitalization ${ }^{4}$.

Wikstrom et al. studied 813 patients included in CARE-HF (The Cardiac Resynchronization - Heart Failure) trial and conclude that the benefits of CRT is similar but ischemic patients have a worse prognosis which may lead to a greater benefit of CRT ${ }^{9}$. In ischemic patients, Bleeker et al. described that presence of scar tissue especially in the posterolateral LV segment prevents proper implantation of the LV lead, therefore resulting in lack of clinical and echocardiographic response to $\mathrm{CRT}^{10}$. Ventricular arrhythmias appear to be more severe in cases of ischemic etiology as compared with non-ischemic cardiomyopathy ${ }^{2}$ probably due to the presence of scar tissue.

Despite the worse prognosis of ischemic patients, in out cohort there was no difference of choice between CRT and CRT with implantable cardioverter- defibrillator support in the ischemic and non-ischemic group (64.2\% respectively $63.3 \%, \mathrm{p}=0.3)$.

\subsection{RV systolic dysfunction and HFrEF etiology}

Multiple studies have proven that RV dysfunction is an independent predictor of survival in patients with moderate and severe $\mathrm{HF}^{11}$. In addition, a work conducted by Field et al. stated that RV dysfunction is also associated with a poorer prognosis in patients undergoing CRT ${ }^{12}$.

In our study, ischemic patients had more severe RV dysfunction with a significantly decreased median TAPSE and RV FAC. In the CARE-HF (The Cardiac Resynchronization - Heart Failure) trial, poor baseline RV function was associated with less improvements in LV function in response to CRT and this trend was accounted for by the high prevalence of ischemic heart disease in patients with RV dysfunction ${ }^{13}$. Worse TAPSE and higher tricuspid regurgitation gradient estimated at baseline were associated with an adverse prognosis and the strong statistical association 
between lower TAPSE and higher prevalence of ischemic etiology ${ }^{14}$.

Despite worse RV dysfunction, our data shows that ischemic CMD responded similarly to non-ischemic CMD after CRT, with no significant differences. An observation made by Tabereaux et al states that, although ischemic patients with RV dysfunction may benefit in terms of clinical improvement after CRT, the presence of $\mathrm{RV}$ dysfunction predicts a poor overall prognostic ${ }^{15}$.

\section{CONCLUSION}

Our data suggest that ischemic etiology of HFrEF is associated with a higher risk of adverse cardiovascular events in patients who received CRT. In part, this may be due to the worse RV systolic dysfunction in these patients, since both ischemic and non-ischemic patients reported similar responses to CRT therapy.

\section{References}

1. Brignole $\mathrm{M}$, Auricchio $\mathrm{A}$, Baron-Esquivias $\mathrm{G}$, Bordachar $\mathrm{P}$, Boriani G, Breithardt O-A, et al. 2013 ESC Guidelines on cardiac pacing and cardiac resynchronization therapy: the Task Force on cardiac pacing and resynchronization therapy of the European Society of Cardiology (ESC). Developed in collaboration with the European Heart Rhythm Association (EHRA). Eur Heart J. 2013;34:2281329.

2. Yokoshiki H, Mitsuyama H, Watanabe M, Mitsuhashi T, Shimizu A. Cardiac resynchronization therapy in ischemic and non-ischemic cardiomyopathy. J Arrhythmia. 2017;33:410-6.

3. Moss AJ, Hall WJ, Cannom DS, Klein H, Brown MW, Daubert JP, et al. Cardiac-resynchronization therapy for the prevention of heart-failure events. N Engl J Med. 2009;361:1329-38.

4. Martens P, Nijst P, Verbrugge FH, Dupont M, Tang WHW, Mullens $W$. Profound differences in prognostic impact of left ventricular reverse remodeling after cardiac resynchronization therapy relate to heart failure etiology. Heart Rhythm. 2018;15:130-6.

5. Rudski LG, Lai WW, Afilalo J, Hua L, Handschumacher MD, Chandrasekaran K, et al. Guidelines for the Echocardiographic Assessment of the Right Heart in Adults: A Report from the American Society of Echocardiography. Endorsed by the European Association of Echocardiography, a registered branch of the European Society of Cardiology, and. J Am Soc Echocardiogr. 2010;

6. Sipahi I, Chou JC, Hyden M, Rowland DY, Simon DI, Fang JC. Effect of QRS morphology on clinical event reduction with cardiac resynchronization therapy: meta-analysis of randomized controlled trials. Am Heart J. 2012;163:260-267.e3.

7. Wang Q, Chen K-Y, Yu F, Su H, An C-S, Hu Y, et al. Abnormal diastolic function underlies the different beneficial effects of cardiac resynchronization therapy on ischemic and non-ischemic cardiomyopathy. Clinics. 2017;72:432-7.

8. McLeod CJ, Shen W-K, Rea RF, Friedman PA, Hayes DL, Wokhlu $A$, et al. Differential outcome of cardiac resynchronization therapy in ischemic cardiomyopathy and idiopathic dilated cardiomyopathy. Heart Rhythm. Elsevier; 2011;8:377-82.

\section{Compliance with ethics requirements:}

The authors declare no conflict of interest regarding this article. The authors declare that all the procedures and experiments of this study respect the ethical standards in the Helsinki Declaration of 1975, as revised in 2008(5), as well as the national law. Informed consent was obtained from all the patients included in the study.

9. Wikstrom G, Blomström-Lundqvist C, Andren B, Lönnerholm S, Blomström P, Freemantle $\mathrm{N}$, et al. The effects of aetiology on outcome in patients treated with cardiac resynchronization therapy in the CARE-HF trial. Eur Heart J. 2009;30:782-8.

10. Bleeker GB, Kaandorp TAM, Lamb HJ, Boersma E, Steendijk P, de Roos A, et al. Effect of posterolateral scar tissue on clinical and echocardiographic improvement after cardiac resynchronization therapy. Circulation. 2006;113:969-76.

11. de Groote P, Millaire A, Foucher-Hossein C, Nugue O, Marchandise $X$, Ducloux G, et al. Right ventricular ejection fraction is an independent predictor of survival in patients with moderate heart failure. J Am Coll Cardiol. 1998;32:948-54.

12. Field $M E$, Solomon $S D$, Lewis $E F$, Kramer $D B$, Baughman $K L$, Stevenson LW, et al. Right ventricular dysfunction and adverse outcome in patients with advanced heart failure. J Card Fail. 2006;12:616-20

13. Cleland JG, Daubert JC, Erdmann E, Freemantle N, Gras D, Kappenberger $L$, et al. The CARE-HF study (CArdiac REsynchronisation in Heart Failure study): rationale, design and end-points. Eur J Heart Fail. 2001;3:481-9.

14. Damy T, Ghio S, Rigby AS, Hittinger L, Jacobs S, Leyva F, et al. Interplay Between Right Ventricular Function and Cardiac Resynchronization Therapy: An Analysis of the CARE-HF Trial (Cardiac Resynchronization-Heart Failure). J Am Coll Cardiol. 2013;61:2153-60.

15. Tabereaux PB, Doppalapudi H, Kay GN, Mcelderry HT, Plumb VJ, Epstein AE. Limited Response to Cardiac Resynchronization Therapy in Patients with Concomitant Right Ventricular Dysfunction. J Cardiovasc Electrophysiol. 2010;21:431-5. 